B. CAKMAK ${ }^{1, \infty}$

T. KARACALI ${ }^{1}$

S. $\mathrm{YU}^{2}$

\section{Theoretical investigation of chirped mirrors in semiconductor lasers}

${ }^{1}$ Ataturk University, Engineering Faculty, Department of Electrical and Electronics, 25240 Erzurum, Turkey

${ }^{2}$ University of Bristol, Room 4.21, Merchant Ventures Building, Woodland Road, Bristol, BS8 1UB, UK

Published online: 23 August 2005 • (C) Springer-Verlag 2005

The publisher failed to print the correct volume number ' 81 ' in this paper. The complete citation is given on the right-hand side.
Appl. Phys. B 81, 33-37 (2005)

DOI: $10.1007 / \mathrm{s} 00340-005-1868-4$

Published online: 14 June 2005

Fax: +90-442-2360957, E-mail: bcakmak@atauni.edu.tr

The online version of the original article can be found at http://dx.doi.org/10.1007/s00340-005-1868-4 